\title{
Law $\mathcal{X}$ Social Inquiry
}

Journal of the American Bar Foundation

Volume 26, Number 4, Fall 2001

The University of Chicago Press 


\section{Law $\&$}

\section{Social Inquiry}

Journal of the American Bar Foundation

Dedicated to the Study of Law,

Legal Institutions, and Legal Processes

Published by The University of Chicago Press

$\begin{array}{ll}\text { Editors } & \begin{array}{l}\text { John Hagan } \\ \text { Laura Beth Nielsen } \\ \text { Victoria Saker Woeste }\end{array} \\ \text { Review Editor } & \text { Howard S. Erlanger } \\ \text { Associate Editors } & \text { Ronit Dinovitzer } \\ & \text { Mary R. Rose } \\ \text { Manuscript Editors } & \text { Susan F. Messer } \\ & \text { Sandy L. Pittman }\end{array}$

\section{Editorial Board}

Richard L. Abel, Professor of Law, University of California, Los Angeles

Richard Bernstein, Adjunct Professor of Law, New York University Law School

John Braithwaite, Professor of Law and Sociology, The Australian National University

Peter Carstensen, Professor of Law, University of Wisconsin School of Law

Marianne Constable, Associate Professor of Rhetoric, University of California

Mary Dudziak, University of Southern California Law School

John J. Donohue, Professor of Law, Stanford Law School

Sarah Gatson, Assistant Professor of Sociology, Texas A\&M University

Howard Gillman, Associate Professor of Political Science, University of Southern California

Sarah Barringer Gordon, Professor of Law, University of Pennsylvania Law School

Carol J. Greenhouse, Professor of Anthropology, Indiana University

Sally Hadden, Assistant Professor of History, Florida State University

Valerie P. Hans, Professor of Criminal Justice, University of Delaware

Allan Lind, Professor of Business Administration and Management, Fuqua School of Business, Duke University

Carrie J. Menkel-Meadow, Professor of Law, Georgetown University

Sally Engle Merry, Professor of Anthropology, Wellesley College

Jennifer Mnookin, University of Virginia Law School

Eric Posner, Professor of Law, University of Chicago School of Law

Joseph Rees, Virginia Polytechnic Institute and State University

Nancy Reichman, Associate Professor of Sociology, University of Denver

Judith Resnik, Professor of Law, Yale University

Michael Silverstein, Professor of Anthropology, University of Chicago

Peter Siegelman, Ph.D., Fordham University Law School

Eve Darian-Smith, Associate Professor of Anthropology, University of California,

Santa Barbara

Susan Sterett, Associate Professor of Political Science, University of Denver

Mark Suchman, Associate Professor of Sociology, University of Wisconsin, Madison

John Sutton, Professor of Sociology, University of California, Santa Barbara

Neil Vidmar, Professor of Law, Duke University 


\section{Law \&}

\section{Social Inquiry}

Volume 26, Number 4, Fall 2001

\section{ARTICLES}

From Betrayal to Violence: Dante's Inferno and the Social

Construction of Crime

Paul G. Chevigny

Knowledge on Tap: Police Science and Common Knowledge in the Legal Regulation of Drunkenness

Ron Levi and Mariana Valverde

Legal Weapons for the Weak? Democratizing the Force

of Words in an Uncivil Society

Orville Lee

\section{REVIEW ESSAY}

Visions of Fact; Languages of Evidence: History, Memory, and the Trauma of Legal Research

Bill Maurer 


\section{Publication Policy}

The American Bar Foundation $(\mathrm{ABF})$ is an independent research institute committed to sociolegal research. Consistent with its mandate to create and disseminate knowledge about law, the legal profession, and legal institutions, Law and Social Inquiry: Journal of the American Bar Foundation invites the submission of articles that make original contributions to understanding sociolegal processes. Law and Social Inquiry publishes both empirical and theoretical studies from a variety of disciplinary perspectives. The analyses, conclusions, and opinions are those of the authors alone.

Manuscript Evaluation: Law and Social Inquiry is a refereed journal. Manuscripts that the Editors deem appropriate for the journal are evaluated by two or more reviewers with expertise in the relevant subject matter and methodology. Manuscripts produced by $\mathrm{ABF}$ research fellows are evaluated by the same process as outside manuscripts and are not accorded priority in publication.

Submission of Manuscripts: Law and Social Inquiry uses the author/date citation system, as described in The Chicago Manual of Style, 14th Edition. You may obtain our style guidelines via surface mail by writing to us at: Editorial Coordinator, Law and Social Inquiry, American Bar Foundation, 750 N. Lake Shore Drive, Chicago, Illinois 60611; or from our Web site at: http://www.journals.uchicago.edu/LSI/. Manuscripts submitted to Law and Social Inquiry should be typed double-spaced and be accompanied by an abstract of not more than 150 words. The review process is anonymous; all identifying information should appear only on a separate cover sheet and not in the body of the manuscript.

Law and Social Inquiry does not accept multiply submitted articles. The Editors endeavor to make decisions promptly, usually about two months after submission.

Editing of Manuscripts: All manuscripts accepted for publication are edited for style by professional copy editors in consultation with the author. Copy editors do not check citations. Authors see edited manuscripts and/or proofs.

Off-Prints to Authors: Without charge, we provide authors with 25 off-prints of their articles, essays, or exchanges (but not symposia) that appear in Law and Social Inquiry. Additional off-prints may be ordered at the author's expense. Authors receive 1 copy of the issue in which their contributions appear.

Republication Rights: The Foundation normally permits authors to republish their manuscripts in books or use their manuscripts after publication, but Law and Social Inquiry has the right to first publication of edited manuscripts. The journal retains the right to republish manuscripts as reprints or as part of any reproduction of the issue or volume in which they appear, by any means, including without limit electronic means or microfilm.

Copying Beyond Fair Use: The code on the first page of a contribution in this journal indicates the copyright owner's consent that copies of the contribution may be made beyond those permitted by Sections 107 or 108 of the U.S. Copyright Law provided that copies are made only for personal or internal use, or for the personal or internal use of specific clients and provided that the copier pay the stated percopy fee through the Copyright Clearance Center, Inc., 222 Rosewood Drive, Danvers, MA 01923. To request permission for other kinds of copying, such as copying for classroom use without charge, copying for general distribution, for advertising or promotional purposes, for creating new collective works, or for resale, kindly write to the Permissions Department, University of Chicago Press, 1427 S. 60th Street, Chicago, IL 60637-2954. 
Comments and Responses: Comments on or responses to articles or review essays in the form of brief, scholarly statements will be published at the discretion of the Editors or Review Section Editor.

Send article manuscripts to: The Editors Law ES Social Inquiry American Bar Foundation 750 N. Lake Shore Drive Chicago, IL 60611 (312) 988-6500
Send inquiries regarding review essays to:

Howard S. Erlanger

Review Editor

Law Eु Social Inquiry

Institute for Legal Studies Law School

University of Wisconsin

Madison, WI 53706

(608) 263-7405

For further information via the Internet-

Web site: http://www.journals.uchicago.edu/LSI/

E-mail: 1si-abf@abfn.org

Law $\mathcal{E}$ Social Inquiry is available for full-text search on the LEXISTM/

NEXISTM $^{\mathrm{TM}}$ and WESTLAW ${ }^{\mathrm{TM}}$ on-line services.

Annual U.S. subscription rates:

$\begin{array}{lcrr} & 1 \mathrm{yr} . & 2 \mathrm{yr} . & 3 \mathrm{yr} . \\ \text { Individuals } & \$ 39 & \$ 71.75 & \$ 99.45 \\ \text { Academic } & \$ 36 & \$ 66.25 & \$ 91.80 \\ \text { Institutions } & \$ 68 & \$ 125.10 & \$ 173.40 \\ \text { Student } & \$ 29 & \$ 53.35 & \$ 73.95\end{array}$

Outside U.S. please add a postage charge of $\$ 6.00$ per year to the U.S. rates. Canadians please add $7 \%$ GST tax to above rates as follows: Oneyear rates: Individuals \$2.73; Academic \$2.52; Institutions \$4.76. Twoyear rates: Individuals \$5.03; Academic \$4.64; Institutions \$8.76. Threeyear rates: Individuals \$6.97; Academic \$6.43; Institutions \$12.14.

Single copies: $\$ 21.00$ for institutions, $\$ 13.75$ for individuals. Checks should be made payable to Law $\mathcal{E}$ Social Inquiry, University of Chicago Press, Journals Division, P.O. Box 37005, Chicago, Illinois 60637. (Fax: 773-753-0811; E-mail: subscriptions@press.uchicago.edu) Volumes 1-12 available from William S. Hein \& Co., Inc., 1285 Main Street, Buffalo, New York 14209. (800) 828-7571.

Volumes available in microfilm from University Microfilms International, 300 North Zeeb Road, Ann Arbor, Michigan 48106.

(C) 2001 American Bar Foundation. All rights reserved.

Law 83 Social Inquiry: Journal of the American Bar Foundation (ISSN: $0897-$ 6546) is published quarterly-winter, spring, summer, and fall-by The University of Chicago Press, 1427 S. 60th Street, Chicago, Illinois 60637 2954. Subscription agent for Japan: Kinokuniya Company, Ltd. Periodicals postage paid at Chicago, Illinois and at additional mailing office. POSTMASTER: Send address changes to: Law $\mathcal{E}$ Social Inquiry, P.O. Box 37005, Chicago, IL 60637. 
